\title{
JUVENILE-MATURE GENETIC CORRELATIONS IN Pinus taeda CLONES PROPAGATED VIA SOMATIC EMBRYOGENESIS ${ }^{1}$
}

\author{
Poliana Coqueiro Dias ${ }^{2 *}$, Aloisio Xavier ${ }^{3}$, Marcos Deon Vilela de Resende ${ }^{4}$, Fabrício Antonio Biernaski ${ }^{5}$, \\ Regiane Abjaud Estopa ${ }^{5}$ and Ismael Eleotério Pires ${ }^{6}$
}

\footnotetext{
${ }^{1}$ Received on 28.04.2014 accepted for publication on 01.12.2015.

${ }^{2}$ Universidade Federal Rural do Semiárido, Departamento de Ciência Vegetal, Mossoró, RN - Brasil. E-mail:<policoqueiro@yahoo.com.br>.

${ }^{3}$ Universidade Federal de Viçosa, Centro de Ciências Agrárias, Departamento de Engenharia Florestal, Viçosa, MG - Brasil. E-mail: <xavier@ufv.br>.

${ }^{4}$ Empresa Brasileira de Pesquisa Agropecuária, Centro Nacional de Pesquisa de Florestas, Colombo, PR - Brasil. E-mail: $<$ marcos.deon@gamil.com>.

${ }^{5}$ Klabin do Paraná Produtos Florestais, KPPF, Brasil. E-mail: <fbiernaski@klabin.com.br> and <restopa@klabin.com.br>.

${ }^{6}$ Universidade Federal de Viçosa, Departamento de Engenharia Florestal, Viçosa, MG - Brasil. E-mail: <iepires@ufv.br>.

${ }^{*}$ Corresponding author.
}

\begin{abstract}
This study aimed to estimate the genetic correlation among selection ages (juvenile - adult) and efficiency of early selection for the height, diameter, and volume traits of individuals from Pinus taeda families propagated via somatic embryogenesis. This study was carried out by genetic-statistical analysis, estimation procedure of variance (Reml), and prediction components of breeding values (Blup), using the Selegen-Reml/ Blup software. Genetic correlations among juvenile ages and rotation age were performed by applying the linear model developed by Lambeth (1980). In accordance with results of the established model, the early selection can be performed in clones of Pinus taeda with high selection efficiency. Ages from 4 to 6 years old are enough to select Pinus taeda clones propagated via somatic embryogenesis for harvesting at 8 and 12 years old; and 6 to 10 years old are enough to select them for harvesting at 20 years old. On the basis of the genetic correlations estimates from the environments, the clones' selection of Pinus taeda propagated via somatic embryogenesis should be developed specifically for each environment. The clones' selection can be performed considering the diameter due to the high correlation between volume and diameter.
\end{abstract}

Keywords: Forest improvement; Clonal forestry; Early selection.

\section{CORRELAÇÃO GENÉTICA JUVENIL-ADULTA EM CLONES DE Pinus taeda PROPAGADOS VIA EMBRIOGÊNESE SOMÁTICA}

\begin{abstract}
RESUMO - objetivou-se com o presente trabalho, estimar a correlação genética entre idades de seleção (juvenil-adulta) e eficiência da seleção precoce para as características altura, diâmetro e volume de indivíduos de famílias de Pinus taeda propagados via embriogênese somática. O estudo foi realizado por meio de análise genético-estatística pelo procedimento de estimação de componentes de variância (Reml) e de predição de valores genéticos (Blup), usando-se o software Selegen-Reml/Blup. As correlações genéticas entre idades juvenis e idade de rotação foram realizadas aplicando o modelo linear desenvolvido por Lambeth (1980). Segundo os resultados do modelo estabelecido, a seleção precoce pode ser realizada em clones de Pinus taeda com alta eficiência de seleção. As idades de 4 a 6 anos são suficientes para selecionar clones de Pinus taeda propagados via embriogênese somática para colheita aos 8 e 12 anos e, as idades de 6 a 10 anos são suficientes para selecionar para colheita aos 20 anos. De acordo com as estimativas de correlação genotípica
\end{abstract}


a partir dos ambientes, a seleção de clones de Pinus taeda propagados via embriogênese somática deve ser praticada de forma específica para cada ambiente. Pode-se realizar a seleção de clones considerando o diâmetro, visto a alta correlação observada entre volume e diâmetro.

Palavras-chave: Melhoramento florestal; Silvicultura clonal; Seleção precoce.

\section{INTRODUCTION}

Techniques of clonal propagation, such as the cutting and minicutting, have shown limitations in the Pinus taeda propagation because of the difficulty for rooting cuttings process from vegetative material in adult phase (WISE; CALDWELL, 1994; ALCANTARA et al., 2007, 2008; ANDREJOW; HIGA, 2009). Considering the importance of clonal propagation of superior genotypes in breeding programs of this species, the technique of somatic embryogenesis has been proposed to remedy these limitations (ISIK et al., 2005; PULLMAN; BUCALO, 2011). There are also reports on this technique feasibility, not only in breeding programs, but also in commercial plantations (MACKAY et al., 2006; PULLMAN et al., 2006; ALCANTARA et al., 2008; ANDREJOW; HIGA, 2009; PULLMAN et al., 2011).

The implementation of early selection and the viability of clonal propagation technique are important aspects in a breeding program. The possibility of early selection reduces the required time to complete a selection cycle and the viability of clonal propagation technique in commercial plantations and increases the genetic gain per selection cycle, since all the genetic variance is explored.

Although aspects related to space and time savings have been mentioned as advantages of early selection (LAMBETH, 1980; REZENDE et al., 1994; WU, 1998; PIRES et al., 2011), its usagee has mainly aimed to reducing the selection cycle duration (LAMBETH, 1980; MCKEAND, 1988; MATHESON etal., 1994; MCKEAND et al., 2006; DEAN, 2008), reducing the required time for evaluation and selection, and maximizing the genetic gain per time unit (year) (REZENDE et al., 1994; LAMBETH;DILL, 2001; GONÇALVES etal., 2005; DEAN, 2008; PIRES et al., 2011.). Thus, in early selection, traits evaluated in the previous rotation ages are used as predictors of traits economically important in rotation age (RESENDE, 1995; DEAN, 2008; PIRES et al., 2011).

Some researchers have developed mathematical models that can relate the genetic correlation present in juvenile age with the age of crop rotation, with minimal losses in genetic gain (LAMBETH, 1980; MAGNUSSEN, 1989; KANG, 1991; MAGNUSSEN; YANCHUKA, 1993; WU, 1998; LAMBETH; DILL, 2001). The model developed by Lambeth (1980) is commonly used to predict the correlations among different selection ages and is adjusted for genetic correlations between juvenile and adult age in Pinus taeda (LAMBETH; DILL, 2001), and the essence is to meet the minimum age for selection with maximum genetic gain.

In this circumstance, this study aimed to estimate genetic correlation among selection ages (juvenileadult) and early selection efficiency for height, diameter, and volume in clonal tests of Pinus taeda individuals propagated via somatic embryogenesis, considering three evaluation ages (1, 3, and 4 years old); and also, it proposes to estimate the genetic correlation among the selection traits and evaluated environments.

\section{MATERIAL AND METHODS}

\subsection{Experimental area and used germplasm}

This study was carried out using genetic-statistical analysis of an experimental network of Pinus taeda belonging to Klabin SA Company (Brazil), consisting of 238 clones propagated via somatic embryogenesis. Data were obtained based on evaluations carried out in four clonal tests, i.e., two located in Paraná (PR) State and two in Santa Catarina (SC) State, Brazil.

According to the Köppen climate classification, the region where the sites 1 and 2 are allocated - state of Santa Catarina - is characterized as Cfb (KLABIN, 2009), and the area where the sites 3 and 4 are allocated - state of Paraná - are in a climate transition region between Cfa and Cfb (KLABIN, 2011). The sites 1 and 2 have lower average temperatures, and a number of frosts greater than the sites 3 and 4; the minimum temperature at sites 1 and 2 is $-9{ }^{\circ} \mathrm{C}$ with 22 frosts on average per year; and the sites 2 and 3 present temperature of $-4.5^{\circ} \mathrm{C}$ with six frosts per year. Regarding the soil classification, site 1 is classified as humic cambisol, aluminic, leptic, clayey, ground slightly corrugated and corrugated; the site 2 is classified as bruno oxisol, 
aluminic, clayey, ground slightly corrugated and corrugated; the site 3 is classified as haplic cambisol, medium texture, corrugated ground and strongly corrugated; and the site 4 is classified as quartz sandy neosol, sandy and light middle texture, corrugated ground and strongly corrugated.

The used germplasm for the tests implementation was composed by the best families of the breeding program of the Klabin SA Company (free and controlled pollination) propagated via somatic embryogenesis. At first, the best individuals from elite families were selected and their immature cones were collected and allocated for clonal propagation by somatic embryogenesis. Through the immature zygotic embryos, somatic embryos individualized per plant were obtained; part of them was cryopreserved and the other part was sent to Klabin SA Company for obtaining seedlings to be used for implanting the clonal tests in the field.

\subsection{Experimental design}

The clonal tests were implemented in the states of Paraná and Santa Catarina, Brazil, in 2007. The experimental design was of incomplete blocks, unbalanced and undefined mode (why was analyzed via mixed model methodology, REML/ BLUP procedure with random effects blocks), with $3 \mathrm{~m} \times 2 \mathrm{~m}$ spacing, with one plant per plot, in four locations (sites), two in Santa Catarina and two in Paraná. Each site was divided into two experiments, even though they are in the same environment, due to the large number of clones and the area occupied by the blocks. Table 1 shows the number of tested blocks and clones which vary in accordance with the experiment. Three batches of commercial seed were used as comparative control.

\subsection{Data collection}

Measurements of Pinus taeda clones were carried out for diameter - diameter at breast height $(d b h)$ (in centimeter, measured at $1.30 \mathrm{~m}$ height), total height - Ht (in meter), volume - $\operatorname{Vol}\left(\mathrm{m}^{3}\right)$, and survival at 1 , 3 , and 4 years old.

The $d b h$ was measured with a diameter tape; the height was obtained with the relascope. The formula below was used to calculate the volume:

$$
V o l=\left(3.1416 \cdot d b h^{2} / 4\right) \cdot H t \cdot 0.5
$$
height.

in which, $d b h$ is diameter at $1.3 \mathrm{~m}$ high; $H t$ is total

Survival was evaluated by counting the number of living trees per clone in the experiment at the time of $d b h$ and $H t$ measurements $(1,3$, and 4 years old).

\subsection{Estimates of genetic and statistics parameters}

Analyzes were made by the estimation of variance components (Reml) and prediction of breeding values (Blup), using the Selegen-Rem1/Blup software (RESENDE, $2002 b)$. For evaluating the variance components, the variables were evaluated individually by location and together by the sites.

For evaluating individuals inside each local, the variables were analyzed with univariate mixed linear model of the Selegen-Reml/Blup software, Design in Incomplete Blocks, and one observation per plot (Model 16) (RESENDE, 2007).

Combined analyzes of the two sites were carried out at each local and also of four sites in both States. The estimate of the variables was carried out by mixed

Table 1 - Description of installed clonal tests with clones of Pinus taeda propagated via somatic embryogenesis. Tabela 1 - Descrição dos testes clonais instalados com clones de Pinus taeda propagados via embriogênese somática. .

\begin{tabular}{|c|c|c|c|c|c|}
\hline States & Local & Experiments & Clones & Number of blocks & Plants/plot \\
\hline \multirow{4}{*}{$\mathrm{SC}$} & \multirow{2}{*}{ Site 1} & 1 & $1-3536-147$ & 126 & 1 \\
\hline & & 2 & $164-178179-215$ & 126 & 1 \\
\hline & \multirow{2}{*}{ Site 2} & 1 & $1-94$ & 6 & 1 \\
\hline & & 2 & $164-193$ & 6 & 1 \\
\hline \multirow{4}{*}{ PR } & \multirow{2}{*}{ Site 3} & 1 & $1-5455-160$ & 126 & 1 \\
\hline & & 2 & $164-196$ & 6 & 1 \\
\hline & \multirow{2}{*}{ Site 4} & 1 & $1-110$ & 6 & 1 \\
\hline & & 2 & $164-179164-238$ & 126 & 1 \\
\hline $\begin{array}{l}\text { Gener } \\
\text { Comm }\end{array}$ & $\begin{array}{l}\text { differe } \\
\text { in the }\end{array}$ & $\begin{array}{l}: \quad 238 \\
\text { ironments: }\end{array}$ & 126 & & \\
\hline
\end{tabular}


linear model, which includes the effect of genotype $\mathrm{x}$ environment interaction, resulting in the variance components and prediction of breeding values, including all locations. Design in Incomplete Blocks, Multiple Sites, and one observation per plot (Model 54) (RESENDE, 2007).

$$
h_{g}^{2}=\frac{\sigma_{g}^{2}}{\sigma_{g}^{2}+\sigma_{g e}^{2}+\sigma_{e}^{2}}=\text { individual heritability in the }
$$
broad sense of individual plots on the block;

$$
c_{g e}^{2}=\frac{\sigma_{g e}^{2}}{\sigma_{g}^{2}+\sigma_{g e}^{2}+\sigma_{e}^{2}}: \text { determination coefficient }
$$

of the genotype $\mathrm{x}$ environment interaction effects;

$\sigma_{g}^{2}=$ genotypic variance;

$\sigma_{g e}^{2}=$ variance of genotype x environment interaction;

$\sigma_{e}^{2}=$ residual variance among plots;

$r_{g l o c}=\frac{\sigma_{g}^{2}}{\sigma_{g}^{2}+\sigma_{g e}^{2}}=\frac{h_{g}^{2}}{h_{g}^{2}+c_{g e}^{2}}:$ genotypic correlation of genetic materials into the environment.

All analyzes were performed via the Selegen-Reml/ Blup software. With the predicted breeding values, genetic correlations among evaluated traits were obtained.

\subsection{Genetic correlation among different ages}

The model developed by Lambeth (1980) was applied to predict genetic correlations among ages for $d b h$, height, and volume at each evaluation site. The equation is represented by:

$$
r_{\mathrm{A}(\mathrm{T} 1, \mathrm{~T} 2)}=\mathrm{a}+\mathrm{b}(\mathrm{LAR})
$$

in which, $r_{\mathbf{A}(\mathbf{T 1}, \mathbf{T 2})}=$ is the genetic correlation estimated between the T1 (early) and T2 ages (end - cutting age); $\mathbf{a}=$ is the intercept; $\mathbf{b}=$ is the regression coefficient; and $\mathbf{L A R}$ is the natural logarithm of the division between early age and rotation age $=\log _{\mathrm{e}}(\mathrm{T} 1 / \mathrm{T} 2)$. Lambeth and Dill (2001) showed that $\mathrm{LAR}^{2}$ is an independent variable to better predict the genetic correlations among ages than LAR by^itself lonely; so, genetic correlation was made up using both the $\mathbf{L A R}$ as $\mathbf{L A R}$.

The early selection efficiency was examined for the studied traits, supposing the same selection intensity for early age and final evaluation age; the selection efficiency was obtained by the equation proposed by Lambeth (1980):

$$
\mathrm{E}=r_{\mathrm{A}(\mathrm{T} 1, \mathrm{~T} 2)}\left(\mathrm{T}_{2} / \mathrm{T}_{1}\right)
$$

in which, $\mathbf{E}=$ is the early selection efficiency relative to gain with selection in the cutting age, i.e., $\mathbf{E}=1$ for selection at the rotation age; $t=i s$ the required time for a generation of selection; $r_{\mathbf{A}(\mathbf{T 1}, \mathbf{T 2})}=$ is the estimated genetic correlation among the T1 (early) and T2 (final - cuttingage) ages.

\section{RESULTS}

\subsection{Genetic correlation among selection traits and sites}

Estimates of genetic correlations in Pinus taeda clones propagated by somatic embryogenesis showed low associations among survival and the other selection traits in the three evaluation ages (Table 2). The values of these estimates were higher for the correlations between the volume and $d b h$ in each evaluation year $(0.88$ in the first year; 0.95 in the third year; and 0.93 in the fourth year), compared with those ones obtained between the volume and height for the clones propagated via somatic embryogenesis, tested in the three evaluation years, considering combined analysis for all environments (Table 2).

The genetic correlations between diameter and height were similarly high; they were positive and greater than 0.88 in the first and third years (Table 2) in Pinus taeda clones propagated through somatic embryogenesis. However, there was downward trend of the correlations relative the years; in the fourth year, lower correlation among these traits was observed (0.52). Comparing the correlation evolution of the high in the three evaluation years with the other evaluation traits, it is concluded that there was a decrease of these correlations (Table 2).

Table 2 shows the genetic correlation by the sites for volume trait in the three ages when the sites were evaluated in pairs. Only the correlation between site 1 and site 2 in the first evaluation year (0.64) could be considered high (RESENDE; DUARTE, 2007). For all other combinations, the correlation ranged from moderate to low magnitude, indicating the importance in selecting specific clones for these environments. In addition to the low correlation and high genotype $\mathrm{x}$ environment interactions, genotype $\mathrm{x}$ environment correlations and interaction of close magnitudes were observed among pairs of locals in the fourth year (Table 2). 
Table 2 - Correlation among genetic selection traits - overall height (Ht), $1.30 \mathrm{~m}$ diameter (dbh), survival (sur), and volume ( vol) - and the genetic correlation among environments in pairs for volume in Pinus taeda clones propagated via somatic embryogenesis in three years of measurement $(1,3$, and 4 years).

Tabela 2 - Correlação genética entre as características de seleção, altura total (Ht), diâmetro a 1,30 m (dap), sobrevivência (sob) e volume (vol), e correlação genética entre os ambientes avaliados dois a dois para a característica volume, em clones de Pinus taeda propagados via embriogênese somática, em três anos de medição (1, 3 e 4 anos).

\begin{tabular}{|c|c|c|c|c|c|c|}
\hline \multirow[t]{2}{*}{ Years } & \multicolumn{6}{|c|}{ Genetic correlations among traits } \\
\hline & $H t \mathrm{x} d b h$ & Htxsur & Htxvol & dbhxsur & dbhxvol & surxvol \\
\hline 1 & 0.890 & 0.171 & 0.869 & 0.197 & 0.887 & 0.202 \\
\hline 3 & 0.881 & 0.217 & 0.874 & 0.236 & 0.952 & 0.171 \\
\hline 4 & 0.523 & 0.103 & 0.456 & 0.251 & 0.932 & 0.353 \\
\hline \multirow[t]{2}{*}{ Years } & \multicolumn{6}{|c|}{ Genetic correlations among sites for volume } \\
\hline & Site $1 \times$ Site 2 & Site $1 \times$ Site 3 & Site $1 \times$ Site 4 & Site $2 x$ Site 3 & Site $2 x$ Site 4 & Site $3 \times$ Site 4 \\
\hline 1 & 0.637 & 0.250 & 0.326 & 0.349 & 0.258 & 0.590 \\
\hline 3 & 0.371 & 0.337 & 0.547 & 0.401 & 0.484 & 0.555 \\
\hline 4 & 0.404 & 0.429 & 0.511 & 0.544 & 0.384 & 0.487 \\
\hline
\end{tabular}

\subsection{Genetic correlation among different ages}

Table 3 shows the estimates of genetic correlation among the ages of 1,3 , and 4 years old, in the four studied environments for height, diameter, volume, and survival in Pinus taeda clones propagated by somatic embryogenesis. Higher correlations were observed between 3 and 4 years old, with little variation among the different sites, between 87 to $91 \%$ in the site 1 ; 92 to $97 \%$ in the site $2 ; 70$ to $94 \%$ in the site 3 ; and 94 to $97 \%$ in the site 4 .

Regardless of the site for each selection trait, the equations using LAR or $\mathrm{LAR}^{2}$ showed similarities in predicting linear coefficient values, slope of the line, and determination coefficient for the Pinus taeda clones propagated by somatic embryogenesis. Despite the equations similarity in predicting the presented coefficients, it is observed that these coefficients in general showed higher values for the equation using LAR. So, to predict the correlation between selection age and selection efficiency, this equation was adopted.

Among the studied sites, combined evaluation at all sites showed lower determination coefficients, ranging from 50 to $70 \%$, which can be explained by different responses to different environments (Table 4).

Table 3 - Genetic correlations between selection ages (1-3; 1-4; and 3-4 years old) for the height (Ht), diameter (dbh), survival (sur), and volume (vol) evaluated by clonal tests propagated via somatic embryogenesis in Pinus taeda located at four sites (site 1 , site 2 , site 3 , and site 4 ).

Tabela 3 -Correlações genéticas entre as idades de seleção (1-3, 1-4, e 3 - 4 anos) para as características altura (Ht), diâmetro (dap), sobrevivência (sob) e volume (vol), avaliados em testes clonais, propagados via embriogênese somática, de Pinus taeda localizados em quatro locais (sítio 1, sítio 2, sítio 3 e sítio 4).

\begin{tabular}{|c|c|c|c|c|c|c|c|c|}
\hline \multirow[t]{3}{*}{ Local } & \multicolumn{2}{|r|}{$\boldsymbol{H t}$} & \multirow{2}{*}{\multicolumn{2}{|c|}{$\frac{d b h}{\text { Ages Correlations }}$}} & \multirow{2}{*}{\multicolumn{2}{|c|}{$\frac{\text { sur }}{\text { Ages Correlations }}$}} & \multicolumn{2}{|r|}{ vol } \\
\hline & \multirow{2}{*}{$\frac{\text { Ages }}{1-3}$} & \multirow{2}{*}{$\frac{\text { Correlations }}{0.59}$} & & & & & \multirow{2}{*}{$\frac{\text { Ages }}{1-3}$} & \multirow{2}{*}{$\frac{\text { Correlations }}{0.55}$} \\
\hline & & & $1-3$ & 0.55 & $1-3$ & 0.41 & & \\
\hline \multirow[t]{3}{*}{ SITE1 } & $1-4$ & 0.48 & $1-4$ & 0.50 & $1-4$ & 0.30 & $1-4$ & 0.50 \\
\hline & $3-4$ & 0.88 & $3-4$ & 0.92 & $3-4$ & 0.87 & $3-4$ & 0.91 \\
\hline & $1-3$ & 0.77 & $1-3$ & 0.75 & $1-3$ & 0.78 & $1-3$ & 0.73 \\
\hline \multirow[t]{3}{*}{ SITE2 } & $1-4$ & 0.66 & $1-4$ & 0.71 & $1-4$ & 0.73 & $1-4$ & 0.70 \\
\hline & $3-4$ & 0.92 & $3-4$ & 0.97 & $3-4$ & 0.95 & $3-4$ & 0.96 \\
\hline & $1-3$ & 0.87 & $1-3$ & 0.83 & $1-3$ & 0.90 & $1-3$ & 0.87 \\
\hline \multirow[t]{3}{*}{ SITE3 } & $1-4$ & 0.65 & $1-4$ & 0.79 & $1-4$ & 0.66 & $1-4$ & 0.80 \\
\hline & $3-4$ & 0.73 & $3-4$ & 0.94 & $3-4$ & 0.70 & $3-4$ & 0.94 \\
\hline & $1-3$ & 0.81 & $1-3$ & 0.69 & $1-3$ & 0.78 & $1-3$ & 0.73 \\
\hline \multirow[t]{2}{*}{ SITE4 } & $1-4$ & 0.76 & $1-4$ & 0.66 & $1-4$ & 0.84 & $1-4$ & 0.71 \\
\hline & $3-4$ & 0.96 & $3-4$ & 0.97 & $3-4$ & 0.94 & $3-4$ & 0.97 \\
\hline
\end{tabular}


Higher determination coefficients were observed for volume and $d b h$ in all studied sites (site $1: d b h=77 \%$ and volume $=84 \%$; site $2: d b h=98 \%$ and volume $=$ $81 \%$; site $3: d b h=95 \%$ and volume $=92 \%$; site $4: d b h$ $=80 \%$ and volume $=86 \%$; combined evaluation of all sites: $d b h=70 \%$ and volume $=62 \%$ ), when using the equation with LAR (Table 4).

Table 5 shows the genetic correlation for height, diameter, and volume at different ages, which varied according to the harvesting age in all sites and for all evaluated selection traits in Pinus taeda clones propagated by somatic embryogenesis. When selecting clones in juvenile ages for harvesting at 20 years old, correlations of lower magnitude were observed; correlations even can be negative in the site 1 for volume selection at the ages of 4 and 6 years old ( -0.338 and -0.013 , respectively).

Regardless of age indicated for harvesting $(8,12$, or 20 years old), the correlation among the ages was increased, with lower values when the selection was performed in juvenile age (Table 5). As the selection of clones was carried out in closest ages to harvesting age, the correlation increases even getting very close or even matching the one performed at the cutting age (Table 5).

Except for the site 1, ages 4 to 6 years old have shown to be enough for selecting Pinus taeda clones propagated by somatic embryogenesis, aiming harvesting at 8 and 12 years old; and 6 to 10 years old are enough for selecting Pinus taeda clones propagated via somatic embryogenesis for harvesting after 20 years old (Table 5). Correlation of 0.80 was considered the cutoff point.

The early selection efficiency of Pinus taeda clones propagated by somatic embryogenesis varied in height, diameter, and volume traits in different environments ( site 1 , site 2 , site 3 , and site 4 ), considering 8,12 , and 20 years old as reference ages (Table 5). Overall, high selection gains per year were observed, when performing the selection of Pinus taeda clones in juvenile age, reaching a selection gain per year 2.2 times higher than the selection made at the 20 years old, when the selection is performed at the 4 years old for the diameter (Table 5).

Although the magnitudes of the selection efficiency have varied with age, the location, trait (Table 5), and selection for volume provides low efficiency at age lower than 8 years old (Table 5). However, for height and diameter, high selection efficiency of the Pinus taeda clones propagated by somatic embryogenesis was observed since the 4 years old (greater than 0.92 ) at all locations, considering 8,12 , and 20 years old as harvesting dates.

\section{DISCUSSION}

\subsection{Genetic correlation among selection traits and local}

The high correlation between the volume and $d b h$ (Table 2) in Pinus taeda clones propagated by somatic embryogenesis means that the selection based on $d b h$ represents the volume with adequate accuracy. However, the decreasing correlation among height and other selection traits over the years may has occurred because the obtained data for height usually present lower measurement accuracy compared to the diameter, and, therefore, more subject to measuring error (XIANG et al., 2003).

High correlations among growth traits were also found by Paludzyszyn Filho et al. (2002) and Martinez et al. (2012) in Pinus taeda propagated by seminiferous way. Strong positive genotypic correlations for growth traits were obtained from Pseudotsuga menziesii clones propagated via somatic embryogenesis (DEAN, 2008). According to Xiang et al. (2003), diameter and volume in Pinus taeda propagated by seminiferous way showed higher genetic correlation over the eight years of study, ranging from 0.8 to 0.9 , similarly to those ones found in this study in Pinus taeda clones propagated by somatic embryogenesis. In clones propagated via somatic embryogenesis of Picea glauca, four years after planting, diameter and volume showed a higher genetic correlation close to 0.8 (WAHID et al., 2012). As noted, the correlation between volume and diameter tend to be high, regardless of evaluation age and the spreading way.

The genetic correlations among evaluated traits in Pinus taeda clones propagated by somatic embryogenesis were always positive (Table 2), indicating that the response to selection on the other trait will always be positive. High and positive correlations suggest that selection for a trait should lead to consistent responses in other traits. However, the diameter is enough for selection in the three ages, 
Table 4 - Linear coefficient (a), slope of the line (b), and coefficient of determination $\left(\mathrm{r}^{2}\right)$ predicted by linear equations to estimate the correlation among selection ages (juvenile-adult) on height $(H t), 1.30 \mathrm{~m}$ diameter $(d b h)$, and volume (vol) obtained from clonal tests of Pinus taeda propagated via somatic embryogenesis, located in four different environments (Site1; Site2; Site3; and Site4).

Tabela 4 - Coeficiente linear (a), inclinação da reta $(b)$ e coeficiente de determinação $(r 2)$ preditos por equações lineares para estimar a correlação entre idades de seleção (juvenil-adulta) nas características altura (Ht), diâmetro a 1,30 m (dap) e volume (vol) obtidas de testes clonais de Pinus taeda propagados via embriogênese somática, localizados em quatro ambientes diferentes (sitio1, sitio2, sitio3 e sitio4).

\begin{tabular}{|c|c|c|c|c|c|c|c|}
\hline \multirow[t]{2}{*}{ Local } & \multirow[t]{2}{*}{ Traits } & \multicolumn{3}{|c|}{ LAR } & \multicolumn{3}{|c|}{$\mathrm{LAR}^{2}$} \\
\hline & & $\mathrm{a}$ & $\mathrm{b}$ & $\mathrm{r}^{2}$ & $\mathrm{a}$ & $\mathrm{b}$ & $\mathrm{r}^{2}$ \\
\hline \multirow[t]{3}{*}{ Site 1} & $H t$ & 1.014 & 0.491 & 0.606 & 0.880 & -0.299 & 0.594 \\
\hline & $d b h$ & 1.101 & 0.519 & 0.767 & 0.968 & -0.324 & 0.750 \\
\hline & vol & 0.953 & 0.348 & 0.840 & 0.860 & -0.214 & 0.844 \\
\hline \multirow[t]{3}{*}{ Site2 } & $H t$ & 0.970 & 0.198 & 0.771 & 0.923 & -0.127 & 0.840 \\
\hline & $d b h$ & 1.030 & 0.229 & 0.979 & 0.965 & -0.137 & 0.933 \\
\hline & vol & 1.028 & 0.273 & 0.809 & 0.948 & -0.161 & 0.750 \\
\hline \multirow[t]{3}{*}{ Site3 } & $H t$ & 0.957 & 0.110 & 0.750 & 0.929 & -0.070 & 0.789 \\
\hline & $d b h$ & 1.027 & 0.173 & 0.946 & 0.978 & -0.103 & 0.894 \\
\hline & vol & 1.019 & 0.153 & 0.921 & 0.977 & -0.092 & 0.892 \\
\hline \multirow[t]{3}{*}{ Site4 } & $H t$ & 0.978 & 0.108 & 0.871 & 0.948 & -0.066 & 0.860 \\
\hline & $d b h$ & 1.021 & 0.166 & 0.797 & 0.973 & -0.099 & 0.748 \\
\hline & vol & 1.028 & 0.190 & 0.865 & 0.974 & -0.114 & 0.819 \\
\hline \multirow[t]{3}{*}{ All Sites } & $H t$ & 0.968 & 0.158 & 0.508 & 0.928 & -0.158 & 0.533 \\
\hline & $d b h$ & 1.024 & 0.208 & 0.701 & 0.965 & -0.125 & 0.666 \\
\hline & vol & 1.021 & 0.223 & 0.623 & 0.958 & -0.133 & 0.590 \\
\hline \multirow[t]{2}{*}{ Local } & Traits & \multicolumn{3}{|c|}{ LAR } & \multicolumn{3}{|c|}{$\mathrm{LAR}^{2}$} \\
\hline & & $\mathrm{a}$ & $\mathrm{b}$ & $r^{2}$ & $\mathrm{a}$ & $\mathrm{b}$ & $r^{2}$ \\
\hline \multirow[t]{3}{*}{ Site 1} & $H t$ & 1.014 & 0.491 & 0.606 & 0.880 & -0.299 & 0.594 \\
\hline & $d b h$ & 1.101 & 0.519 & 0.767 & 0.968 & -0.324 & 0.750 \\
\hline & vol & 0.953 & 0.348 & 0.840 & 0.860 & -0.214 & 0.844 \\
\hline \multirow[t]{3}{*}{ Site2 } & $H t$ & 0.970 & 0.198 & 0.771 & 0.923 & -0.127 & 0.840 \\
\hline & $d b h$ & 1.030 & 0.229 & 0.979 & 0.965 & -0.137 & 0.933 \\
\hline & vol & 1.028 & 0.273 & 0.809 & 0.948 & -0.161 & 0.750 \\
\hline \multirow[t]{3}{*}{ Site3 } & $H t$ & 0.957 & 0.110 & 0.750 & 0.929 & -0.070 & 0.789 \\
\hline & $d b h$ & 1.027 & 0.173 & 0.946 & 0.978 & -0.103 & 0.894 \\
\hline & vol & 1.019 & 0.153 & 0.921 & 0.977 & -0.092 & 0.892 \\
\hline \multirow[t]{3}{*}{ Site 4} & $H t$ & 0.978 & 0.108 & 0.871 & 0.948 & -0.066 & 0.860 \\
\hline & $d b h$ & 1.021 & 0.166 & 0.797 & 0.973 & -0.099 & 0.748 \\
\hline & vol & 1.028 & 0.190 & 0.865 & 0.974 & -0.114 & 0.819 \\
\hline \multirow[t]{3}{*}{ All Sites } & $H t$ & 0.968 & 0.158 & 0.508 & 0.928 & -0.158 & 0.533 \\
\hline & $d b h$ & 1.024 & 0.208 & 0.701 & 0.965 & -0.125 & 0.666 \\
\hline & vol & 1.021 & 0.223 & 0.623 & 0.958 & -0.133 & 0.590 \\
\hline \multirow[t]{2}{*}{ Local } & Traits & \multicolumn{3}{|c|}{ LAR } & \multicolumn{3}{|c|}{$\mathrm{LAR}^{2}$} \\
\hline & & $\mathrm{a}$ & $\mathrm{b}$ & $\mathrm{r}^{2}$ & $\mathrm{a}$ & $\mathrm{b}$ & $\mathrm{r}^{2}$ \\
\hline \multirow[t]{3}{*}{ Site 1} & $H t$ & 1.014 & 0.491 & 0.606 & 0.880 & -0.299 & 0.594 \\
\hline & $d b h$ & 1.101 & 0.519 & 0.767 & 0.968 & -0.324 & 0.750 \\
\hline & vol & 0.953 & 0.348 & 0.840 & 0.860 & -0.214 & 0.844 \\
\hline \multirow[t]{3}{*}{ Site2 } & $H t$ & 0.970 & 0.198 & 0.771 & 0.923 & -0.127 & 0.840 \\
\hline & $d b h$ & 1.030 & 0.229 & 0.979 & 0.965 & -0.137 & 0.933 \\
\hline & vol & 1.028 & 0.273 & 0.809 & 0.948 & -0.161 & 0.750 \\
\hline Site3 & $H t$ & 0.957 & 0.110 & 0.750 & 0.929 & -0.070 & 0.789 \\
\hline & $d b h$ & 1.027 & 0.173 & 0.946 & 0.978 & -0.103 & 0.894 \\
\hline & vol & 1.019 & 0.153 & 0.921 & 0.977 & -0.092 & 0.892 \\
\hline Site4 & $H t$ & 0.978 & 0.108 & 0.871 & 0.948 & -0.066 & 0.860 \\
\hline
\end{tabular}


Table 4 - Cont.

Tabela 4-Cont.

\begin{tabular}{|c|c|c|c|c|c|c|c|}
\hline & $d b h$ & 1.021 & 0.166 & 0.797 & 0.973 & -0.099 & 0.748 \\
\hline \multirow{3}{*}{ All Sites } & vol & 1.028 & 0.190 & 0.865 & 0.974 & -0.114 & 0.819 \\
\hline & $\begin{array}{c}H t \\
\mathrm{dbh}\end{array}$ & $\begin{array}{l}0.968 \\
1.024\end{array}$ & $\begin{array}{l}0.158 \\
0.208\end{array}$ & $\begin{array}{l}0.508 \\
0.701\end{array}$ & $\begin{array}{l}0.928 \\
0.965\end{array}$ & $\begin{array}{l}-0.158 \\
-0.125\end{array}$ & $\begin{array}{l}0.533 \\
0.666\end{array}$ \\
\hline & vol & 1.021 & 0.223 & 0.623 & 0.958 & -0.133 & 0.590 \\
\hline
\end{tabular}

due to the high values observed on genetic correlations among growth traits in Pinus taeda clones propagated by somatic embryogenesis.

On the basis of the results presented for the genetic correlation among the environments, aiming to produce individuals for installation of clonal tests and subsequent selection for commercial plantations, it is considered that the breeding program in the studied sites have to take into account the four distinctly environments ( site 1 , site 2 , site 3 , and site 4). The low estimates of correlation may result in changes among the genotypes order when grown in different environments (ROTH et al., 2007). According to Resende (2002), population of single improvement with selection of stable materials (selection by average of locations) must be adopted when the value of the genetic correlation among sites is between 0.70 and 0.90 , values above of the ones found in this study.

Paludzyszyn Filho et al. (2001) evaluated Pinus taeda progenies in four different locations, suggesting that the breeding program should be specific by site due to the low correlation among the environments. On the other hand, Martínez et al. (2012) suggest a single breeding program for Pinus taeda propagated by seminiferous way for different studied locations, due to the high genetic correlation among environments. Dean (2008) and Wahid et al. (2012) observed in Pseudotsuga menziesii and Picea glauca clones propagated via somatic embryogenesis, respectively, high genetic correlation among different clonal tests for all growth traits. The selection option by location or combined selection depends directly on the selected genotypes at each location, their heritability, and genetic correlations.

\subsection{Genetic correlation among different ages}

The highest correlations between 3 and 4 years old in Pinus taeda clones propagated by somatic embryogenesis are consistent with other studies in
Pinus taeda propagated by seminiferous way, addressing genetic correlations for growth traits among different ages (GWAZE et al., 2001; PALUDZYSZYN FILHO et al., 2002; XIANG et al., 2003). According to the accuracy estimates, the trait begins to stabilize genetically as from 3 years old. There is, therefore, tendency of higher genetic correlations after 3 years old. Thus, there is greater accuracy of early selection when ages are adopted with high genetic correlation with mature age and there is some genetic stability of traits under selection. In Pinus, trend of higher correlations among the more mature ages has been observed, while the correlations among very juvenile ages and mature ages have shown low correlation (KUMAR; LEE, 2003; LI; WU, 2005; DEAN et al., 2006; WU et al., 2007; GASPAR et al., 2008).

Regarding the linear coefficient and slope of the line, estimated for Pinus taeda clones propagated via somatic embryogenesis, close values to those ones found by Lambeth (1980) and Lambeth and Dill (2001) have been found in Pinus taeda populations propagated by seminiferous way. Therefore, there is similarity among equations of the juvenile-adult correlation of clonal populations and seminal populations.

Considering the results obtained with the application of Lambeth equation (1980), the volume and $d b h$ are, therefore, more favorable traits for selection with projection in ages due to the higher determination coefficients. Other Studies also show that the model employed by Lambeth (1980) is a good predictor for the genetic correlations among juvenile and mature ages (XIE; YING, 1996; GWAZE et al., 2001; LAMBETH; DILL, 2001; CHEN et al., 2003; WENG et al., 2007; WU et al., 2007).

According to the results shown in Table 5, the Lambeth's model can be used in the prediction of correlations among juvenile and adult ages of Pinus taeda clones propagated via somatic embryogenesis. Therefore, it is a practical model that captures the biological norm of correlation among different ages, that is, the 
Table 5 - Correlation (cor) among ages selection (juvenile - adult) and selection efficiency (E) for the height $(H t), 1.30$ $\mathrm{m}$ diameter $(\mathrm{dbh})$, and volume ( $\mathrm{vol}$ ) traits obtained from clonal tests of Pinus taeda propagated via somatic embryogenesis, located in four different environments (Site1; Site2; Site3; and Site4), with 8, 12, and 20 years old as reference ages for correlation with youth ages.

Tabela 5 - Correlação (cor) entre idades de seleção (juvenil-adulta) e eficiência de seleção (E) para as características altura (Ht), diâmetro a $1,30 \mathrm{~m}$ (dap) e volume (vol) obtidas de testes clonais de Pinus taeda propagados via embriogênese somática, localizados em quatro ambientes diferentes (sítio1, sítio2, sítio3 e sítio4), considerando 8, 12 e 20 anos, como idades de referência para a correlação com idades juvenis.

\begin{tabular}{|c|c|c|c|c|c|c|c|c|c|c|c|}
\hline \multirow[t]{2}{*}{ Characteristics } & \multirow{2}{*}{$\begin{array}{c}\text { Selection } \\
\text { Age }\end{array}$} & \multicolumn{2}{|c|}{ Site 1} & \multicolumn{2}{|c|}{ Site 2} & \multicolumn{2}{|c|}{ Site 3} & \multicolumn{2}{|c|}{ Site 4} & \multicolumn{2}{|c|}{ All sites } \\
\hline & & Cor & $\mathrm{E}$ & Cor & $\mathrm{E}$ & Cor & E & Cor & $\mathrm{E}$ & Cor & $\mathrm{E}$ \\
\hline \multirow{14}{*}{$\boldsymbol{H t}$} & $4-8$ & 0.673 & 0.925 & 0.831 & 1.143 & 0.884 & 1.216 & 0.904 & 1.243 & 0.859 & 1.181 \\
\hline & $6-8$ & 0.872 & 1.163 & 0.912 & 1.216 & 0.928 & 1.237 & 0.948 & 1.264 & 0.924 & 1.232 \\
\hline & $4-12$ & 0.474 & 0.889 & 0.750 & 1.406 & 0.839 & 1.573 & 0.859 & 1.611 & 0.794 & 1.489 \\
\hline & $6-12$ & 0.673 & 1.010 & 0.831 & 1.247 & 0.884 & 1.326 & 0.904 & 1.356 & 0.859 & 1.289 \\
\hline & $8-12$ & 0.814 & 1.018 & 0.889 & 1.111 & 0.915 & 1.144 & 0.935 & 1.169 & 0.905 & 1.131 \\
\hline & $10-12$ & 0.924 & 0.990 & 0.934 & 1.001 & 0.940 & 1.007 & 0.960 & 1.029 & 0.941 & 1.008 \\
\hline & $4-20$ & 0.223 & 0.641 & 0.648 & 1.863 & 0.783 & 2.251 & 0.803 & 2.309 & 0.712 & 2.047 \\
\hline & $6-20$ & 0.422 & 0.971 & 0.729 & 1.677 & 0.828 & 1.904 & 0.848 & 1.950 & 0.777 & 1.787 \\
\hline & $8-20$ & 0.564 & 1.081 & 0.787 & 1.508 & 0.859 & 1.646 & 0.879 & 1.685 & 0.823 & 1.577 \\
\hline & $10-20$ & 0.673 & 1.106 & 0.831 & 1.365 & 0.884 & 1.452 & 0.904 & 1.485 & 0.859 & 1.411 \\
\hline & $12-20$ & 0.762 & 1.095 & 0.868 & 1.248 & 0.904 & 1.300 & 0.924 & 1.328 & 0.888 & 1.277 \\
\hline & $14-20$ & 0.838 & 1.071 & 0.899 & 1.149 & 0.921 & 1.177 & 0.941 & 1.202 & 0.913 & 1.167 \\
\hline & $16-20$ & 0.904 & 1.040 & 0.925 & 1.064 & 0.935 & 1.075 & 0.955 & 1.098 & 0.934 & 1.074 \\
\hline & $18-20$ & 0.962 & 1.006 & 0.949 & 0.992 & 0.948 & 0.991 & 0.968 & 1.012 & 0.953 & 0.996 \\
\hline \multirow{14}{*}{$d b h$} & 4-8 & 0.740 & 1.018 & 0.821 & 1.129 & 0.912 & 1.254 & 0.902 & 1.240 & 0.874 & 1.202 \\
\hline & $6-8$ & 0.951 & 1.268 & 0.914 & 1.219 & 0.981 & 1.308 & 0.971 & 1.295 & 0.960 & 1.280 \\
\hline & $4-12$ & 0.529 & 0.992 & 0.727 & 1.363 & 0.843 & 1.581 & 0.833 & 1.562 & 0.789 & 1.479 \\
\hline & $6-12$ & 0.740 & 1.110 & 0.821 & 1.232 & 0.912 & 1.368 & 0.902 & 1.353 & 0.874 & 1.311 \\
\hline & $8-12$ & 0.889 & 1.111 & 0.887 & 1.109 & 0.961 & 1.201 & 0.951 & 1.189 & 0.935 & 1.169 \\
\hline & $10-12$ & 1.005 & 1.077 & 0.938 & 1.005 & 0.999 & 1.070 & 0.989 & 1.060 & 0.982 & 1.052 \\
\hline & $4-20$ & 0.263 & 0.756 & 0.610 & 1.754 & 0.756 & 2.174 & 0.746 & 2.145 & 0.682 & $\overline{1.961}$ \\
\hline & $6-20$ & 0.474 & 1.090 & 0.703 & 1.617 & 0.825 & 1.898 & 0.815 & 1.875 & 0.767 & 1.764 \\
\hline & $8-20$ & 0.624 & 1.196 & 0.769 & 1.474 & 0.874 & 1.675 & 0.864 & 1.656 & 0.828 & 1.587 \\
\hline & $10-20$ & 0.740 & 1.216 & 0.821 & 1.349 & 0.912 & 1.498 & 0.902 & 1.482 & 0.874 & 1.436 \\
\hline & $12-20$ & 0.834 & 1.199 & 0.862 & 1.239 & 0.943 & 1.356 & 0.933 & 1.341 & 0.913 & 1.312 \\
\hline & $14-20$ & 0.914 & 1.168 & 0.898 & 1.147 & 0.969 & 1.238 & 0.959 & 1.225 & 0.945 & 1.208 \\
\hline & $16-20$ & 0.984 & 1.132 & 0.929 & 1.068 & 0.992 & 1.141 & 0.982 & 1.129 & 0.973 & 1.119 \\
\hline & $18-20$ & 1.000 & 1.093 & 0.956 & 0.999 & 1000 & 1.058 & 1.000 & 1048 & 0.998 & 1.043 \\
\hline \multirow{14}{*}{ vol } & $4-8$ & 0.396 & 0.545 & 0.593 & 0.815 & 0.777 & 1.068 & 0.725 & 0.997 & 0.868 & 1.194 \\
\hline & $6-8$ & 0.720 & 0.960 & 0.849 & 1.132 & 0.919 & 1.225 & $\mathbf{0 . 9 0 3}$ & 1.204 & 0.957 & 1.276 \\
\hline & $4-12$ & 0.071 & 0.133 & 0.338 & 0.634 & 0.635 & 1.191 & 0.547 & 1.026 & 0.778 & 1.459 \\
\hline & $6-12$ & 0.396 & 0.594 & 0.593 & 0.890 & 0.777 & 1.166 & 0.725 & 1.088 & 0.868 & 1.302 \\
\hline & $8-12$ & 0.626 & 0.783 & 0.775 & 0.969 & 0.878 & 1.098 & 0.852 & 1.065 & 0.931 & 1.164 \\
\hline & $10-12$ & 0.804 & 0.861 & 0.915 & 0.980 & 0.956 & 1.024 & 0.950 & 1.018 & 0.980 & 1.050 \\
\hline & $4-20$ & -0.338 & -0.972 & 0.016 & 0.046 & 0.457 & 1.314 & 0.322 & 0.926 & 0.666 & $\overline{1.915}$ \\
\hline & $6-20$ & -0.013 & -0.030 & 0.271 & 0.623 & 0.599 & 1.378 & 0.500 & 1.150 & 0.755 & 1.737 \\
\hline & $8-20$ & 0.217 & 0.416 & 0.453 & 0.868 & 0.699 & 1.340 & 0.627 & 1.202 & 0.818 & 1.568 \\
\hline & $10-20$ & 0.396 & 0.651 & 0.593 & 0.974 & 0.777 & 1.277 & 0.725 & 1.191 & 0.868 & 1.426 \\
\hline & $12-20$ & 0.541 & 0.778 & 0.708 & 1.018 & 0.841 & 1.209 & 0.805 & 1.157 & 0.908 & 1.305 \\
\hline & $14-20$ & 0.664 & 0.848 & 0.805 & 1.029 & 0.895 & 1.144 & 0.873 & 1.116 & 0.941 & 1.202 \\
\hline & $16-20$ & 0.772 & 0.888 & 0.890 & 1.024 & 0.942 & 1.083 & 0.932 & 1.072 & 0.971 & 1.117 \\
\hline & $18-20$ & 0.866 & 0.905 & 0.964 & 1.008 & 0.983 & 1.028 & 0.984 & 1.029 & 0.997 & 1.042 \\
\hline
\end{tabular}


closer to the harvesting age (20 years old), the higher the correlation and vice versa (LAMBETH; Dill, 2001; GWAZE et al., 2001; CHEN et al., 2003; WENG et al., 2007; WU et al., 2007).

The presence of correlation among the ages established for cutting ages and juvenile ages indicates that the early selection of Pinus taeda clones propagated via somatic embryogenesis can be effective in relation to the diameter, height, and volume. Similar results were observed by other authors, studying early selection of Pinus taeda (MCKEAND, 1988; GWAZE et al., 2001; PALUDZIN FILHO et al., 2002; XIANG et al., 2003).

Other studies confirm that early selection in juvenile ages of 4 to 8 years old is reliable for growth traits at the rotation age, and it is the most suitable for early selection in Pinus taeda (ISIK; FRAMPTON, 2003; XIANG et al., 2003). Dean (2008) noted that the age of 4 years old is the most appropriate for the Pseudotsuga menziesii clones' selection propagated via somatic embryogenesis for harvesting at 8 years old.

The correlations among early and late ages suggest that different physiological mechanisms are involved in different development stages, which can be assigned to different genes expression. However, the expression of these genes will stabilize over the years (Table 2), which is shown by the high correlation among half rotation ages and rotation ages (Table 5). This trend was also observed by other authors when studying the early selection in Pinus (HODGE; WHITE, 1992; GOLDSTEIN; HOLSINGER, 1992; JANSSON etal., 2003; WENG et al., 2007).

The observed high efficiency of selection shows that it is possible to perform selection of Pinus taeda clones propagated via somatic embryogenesis older than 4 years old, regarding to the height and diameter. Studies in coniferous have shown the efficiency of early selection based on the correlation among different ages (WU et al., 2007; WENG et al., 2007; DEAN, 2008).

According to Lambert and Bill (2001), the selection efficiency, expressed as the ratio between age and gain in early selection harvesting ages, provides an effective alternative to decisions about the optimal age for performing early selection. These authors note that early selection corresponds to an indirect selection; so, the gain on early selection tends to be smaller than the gain at the age of crop rotation. However, if there is a positive genetic correlation among the evaluated traits in previous ages and the rotation age, early selection can reduce the required time for evaluation and selection, maximizing the genetic gains per time unit (year) (REZENDE et al., 1994; LAMBETH; DILL, 2001; GONÇALVES et al., 2005; DEAN, 2008; PIRES et al., 2011).

Considering the above, the importance of early selection is evident in the programs of forest species improvement, mainly because of the long cycle of forest crops, the need for higher yielding genotypes, the gain with selection in time unit, and the maintenance costs of improvement programs in long-term.

\section{CONCLUSIONS}

The selection of Pinus taeda clones propagated via somatic embryogenesis based on diameter expresses the volume with adequate accuracy.

Due to the low genotypic correlation in different environments, selecting specific clones for each environment is required.

Ages of 4 to 6 years old have shown to be enough to select Pinus taeda clones propagated via somatic embryogenesis for harvesting after 8 and 12 years old, and ages of 6 to 10 years old to harvesting after 20 years.

\section{ACKNOWLEDGEMENT}

We thank Klabin S.A for giving the data to research. This work was supported by the Capes (grant to PC Dias) and CNPq for financial support.

\section{REFERENCES}

ALCANTARA, G. B. de; RIBAS, L. L. F.; HIGA, A. R.; RIBAS, K. C. Z. Efeitos do ácido indolilbutírico (AIB) e da coleta de brotações em diferentes estações do ano no enraizamento de miniestacas de Pinus taeda L. Scientia Forestalis, v.36, n.78, p.151-156, 2008.

ALCANTARA, G. B.; RIBAS, L. L. F.; HIGA, A R.; ZUFFELLATO-RIBAS, K. C; KOEHLER, H. S Efeito da idade da muda e da estação do ano no enraizamento de miniestacas de Pinus taeda $\mathrm{L}$. Revista Árvore, v.31, n.3, p.399-404, 2007.

ANDREJOW, G.M.P.; HIGA, A.R. Potencial de enraizamento de miniestacas de Pinus Taeda L. 
provenientes de brotação apical de mudas jovens. Floresta, v.39, n.4, p.897-903, 2009.

CHEN, X.; HAWKINS, B.; XIE, C. Y.; YING, C. C. Age trends in genetic parameters and early selection of lodgepole pine provenances with particular reference to the Lambeth model. Forest Genetics, v. 10, n.3, p.249-258, 2003.

DEAN, C.A. Genetic parameters of somatic clones of coastal douglas-fir at $51 / 2$-years across Washington and Oregon, USA. Silvae Genetica, v.57, n.4/5, p.269-275, 2008.

DEAN, C.A.; COTTERILL, P.P.; BURDON, R.D. Early Selection of Radiata Pine. Silvae Genetica, v.55, p.182-191, 2006.

GASPAR, M. J.; LOUZADA, J. L.; SILVA, M. E.; AGUIAR, A.; ALMEIDA, M. H. Age trends in genetic parameters of wood density componentes in 46 half-sibling families of Pinus pinaster.

Canadian Journal of Forest Research, v.38, n.6, p.1470-1477, 2008.

GOLDSTEIN, D. B.; HOLSINGER, K. E.:

Maintenance of polygenic variation in spatially structured populations: roles for local mating and genetic redundancy. Evolution, v. 46, p. $412-$ $429,1992$.

GONÇALVES, P.de S.; BORTOLETTO, N.; CARDINAL, A. B.; GOUVÊA, L. R. L.; COSTA, R. B.; MORAES, M. L. T. Age-age correlation for early selection of rubber tree genotypes in São Paulo State, Brazil. Genetics and Molecular Biology, v.28, n.4, p.758-764, 2005.

GWAZE, D. P.; BRIDGWATER, F. E.; BYRAM, T. D.; LOWE, W. J. Genetic parameter estimates for growth and wood density in Loblolly pine (Pinus taeda L.). Forest Genetics, v.8, n.1, p.47-55, 2001.

HODGE, G.R.; WHITE, T.L. Genetic parameter estimates for growth traits at different ages in slash pine and some implications for breeding. Silvae Genetic, v.41, n.4/5, p.252-262, 1992.

ISIK, F.; GOLDFARB, B.; LEBUDE, A.; LI, B.; MCKEAND, S. Predicted genetic gains and testing efficiency from two loblolly pine clonal trials. Canadian Journal Forest Research, v.35, p.1754-1766, 2005.
ISIK, F.; LI, B.; FRAMPTON, J. Estimates of additive, dominance and epistatic genetic variances from a clonally replicated test of loblolly pine. Forest Science, v.49, n.1, p.7788, 2003.

JANSSON, G.; JONSSON, A.; ERIKSSON, G. Efficiency of Early Testing in Pinus sylvestris L. Grown Under Two Different Spacings in Growth Chamber. Silvae Genetica, v.47,p.289-306, 2003.

KANG, H. Components of juvenile-mature correlations in forest trees. Theoretical and Applied Genetics, v.81, p.173-184, 1991.

KLABIN. Plano de manejo florestal 2011: resumo público Telêmaco Borba - PR. Telêmaco Borba:Klabin, 2011. 24p.

KLABIN. Plano de manejo florestal: resumo público Santa Catarina. Otacílio Costa: Klabin, 2009. 12p.

KUMAR, S.; LEE, J. Age-age correlations and early selection for end-of-rotation wood density in Radiata pine. Forest Genetics, v.9, n.4, p.323-330, 2003.

LAMBETH, C.C. Juvenile-mature correlations in Pinaceae and implications for early selection. Forest Science, v.26, p.571-580, 1980.

LAMBETH, C.C.; DILL, L.A. Prediction models for juvenile-mature correlations for loblolly pine growth traits within, between and across test sites. Forest Genetics, v.8, n.2, p.101-108, 2001.

LI, L.; WU, H.X. Efficiency of early selection for rotation-aged growth and wood density traits in Pinus radiate. Canadian Journal Forest Research, v.35, n.1, p.1-11, 2005.

MACKAY, J. J.; BECWAR, M R.; PARK, Y. S.; CORDERRO, J. P.; PULLMAN, G. S. Genetic control of somatic embryogenesis initiation in loblolly pine and implications for breeding. Tree Genetics and Genomes, v.2, n.1, p.1-9, 2006.

MAGNUSSEN, S. Age-to-age correlations in growth processes with fixed and random effects. Silvae Genetica, v.38, n.2, p.49-55, 1989.

Revista Árvore, Viçosa-MG, v.40, n.2, p.255-267, 2016

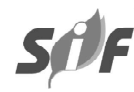


MAGNUSSEN, S.; YANCHUKA, D. Selection age and risk: Finding the compromise. Silvae Genetica, v.42, n.1, p.25-40, 1993.

MARTINEZ, D. T.; RESENDE, M. D. V.; COSTA, R. B.; HIGA, A. R.; SANTOS, G. A.; FIER, I. S. N. Estudo da interação genótipo $\mathrm{x}$ ambiente em progênies de Pinus taeda por meio da análise de parâmetros genéticos. Floresta, v.42, n.3, p.539$552,2012$.

MATHESON, A.C.; SPENCER, D.J.; MAGNUSSEN, D. Optimum age for selection in Pinus radiata basal area under bark for age: age correlations. Silvae Genetica, v.43, p.352-357, 1994.

MCKEAND, S.E. Optimum age for family selection for growth in genetics tests of Loblolly pine. Forest Science, v.34, p.400-411, 1988.

MCKEAND, S.E.; JOKELA, E.J.; HUBER, D.A.; BYRAM, T.D.; ALLEN, H.L.; LI, B.; MULLIN, T.J. Performance of improved genotypes of loblolly pine across different soils, climates and silvicultural inputs. Forestry Ecology Management, v. 227, n.1-2, p.178-184, 2006.

PALUDZYSZYN FILHO, E.; FERNANDES, J.S.C.; RESENDE, M.D.V. Avaliação e seleção precoce para crescimento de Pinus taeda. Pesquisa Agropecuária Brasileira, v.37, n.12, p.17191726, 2002.

PALUDZYSZYN FILHO, E.; MORA, A.L.; MAESTRI, R. Interação de genótipos de Pinus taeda L. com locais no sul-sudeste do Brasil. Revista Cerne, v.7, n.1, p.90-100, 2001.

PIRES, E. L.; RESENDE, M. D. V.; SILVA, R. S.; RESENDE, M. F. R. Jr. Genética florestal. Viçosa, MG: Arka, 2011.318p.

PULLMAN, G.S.; BUCALO, K. Pine somatic embryogenesis using zygotic embryos as explants. Methods in Molecular Biology, v.710, p.267-291, 2011.

PULLMAN, G.S.; CHOPRA, R.; CHASE, K.M. Loblolly pine (Pinus taeda L.) somatic embryogenesis: improvements in embryogenic tissue initiation by supplementation of medium with organic acids, vitamins $B_{12}$ and E. Plant Science, v.170, p.648-658, 2006.
RESENDE, M.D.V.; DUARTE, J.B. Precisão e controle de qualidade em experimentos de avaliação de cultivares. Pesquisa

Agropecuária Tropical, v.37, n.3, p.182-194, 2007.

RESENDE, M.D.V. Delineamento de experimentos de seleção para a maximização da acurácia seletiva e progresso genético. Revista Árvore, v.19, n.4, p.479-500, 1995.

RESENDE, M.D.V. Genética biométrica e estatística no melhoramento de plantas perenes. Brasília: Embrapa Informação Tecnológica; Colombo: Embrapa Florestas, 2002a. 975p.

RESENDE, M.D.V. Software SELEGENREML/BLUP. Colombo: Embrapa Florestas, 2002b. 67 p. (Documentos, 77).

RESENDE, M.D.V. Selegem - Reml/ Blup:Sistema estatístico e Seleção genética computadorizada via modelos lineares mistos. Colombo: Embrapa Florestas, 2007.361p.

REZENDE, G.D.S.P.; BERTOLUCCI, F.L.G.; RAMALHO, M.A.P. Eficiência da seleção precoce na recomendação de clones de eucalipto avaliados no norte do Espírito Santo e Sul da Bahia. Cerne, v.1, n.1, p.45-50, 1994.

ROTH, B. E.; JOKELA, E. J.; MARTIN, T. A., HUBER, D. A.; WHITE, T. L. Genotype environment interactions in selected loblolly and slash pine plantations in the Southeastern United States. Forest Ecology and Management, v.238, p.175-188, 2007.

WAHID, N.; RAINVILLE, A.; LAMHAMEDI, M. S.; MARGOLIS, H. A.; BEAULIEU, J.; DEBLOIS, J. Genetic parameters and performance stability of white spruce somatic seedlings in clonal tests. Forest Ecology and Management, v.27, n. 1, p.45-53, 2012.

WENG, Y. H.; TOSH, K. J.; PARK, Y. S.;

FULLARTON, M. S. Age-related trends in genetic parameters for jack pine and their implications for early selection. Silvae Genetica, v.56, n.5, p.242-252, 2007. 
WISE, F.; CALDWELL, T. Macropropagation of conifers by stem cuttings. In: Proceedings of the Southern regional information Exchange Group Biennial Symposium on Forest Genetics: Applications of Vegetative Propagation in Forestry. Huntsville: 1994. p.51-73.

WENG, Y. H.; TOSH, K. J.; PARK, Y. S.;

FULLARTON, M. S. Efficiency of early selection for rotation-aged wood quality traits in Radiata pine. Forest Science, v.64, n.1, p.1-9, 2007.
WU, H. X.; POWEL, M. B.; YANG, J. L.; IVKOVIC, M.; MCRAE, T. A. Study of early selection in tree breeding: 1. Advantage of early selection through increasing selection intensity and reduction of field test size. Silvae Genetica, v.47, n.2, p.146-155, 1998.

XIANG, B.; LI, B.; ISIK, F. Time trend of genetic parameters in growth traits of Pinus taeda L. Silvae Genetica, v.52, n.1, p.114121, 2003. 